University for Business and Technology in Kosovo

UBT Knowledge Center

UBT International Conference

2017 UBT International Conference

Oct 28th, 1:00 PM - 2:30 PM

\title{
Process of State-building in Kosovo
}

Ngadhnjim Brovina

Ilira College, ngadhnjim.brovina@uiliria.org

Adlum Ramadani

Ilira College, adlum.ramadani@uiliria.org

Follow this and additional works at: https://knowledgecenter.ubt-uni.net/conference

Part of the International Relations Commons

\section{Recommended Citation}

Brovina, Ngadhnjim and Ramadani, Adlum, "Process of State-building in Kosovo" (2017). UBT International Conference. 315.

https://knowledgecenter.ubt-uni.net/conference/2017/all-events/315

This Event is brought to you for free and open access by the Publication and Journals at UBT Knowledge Center. It has been accepted for inclusion in UBT International Conference by an authorized administrator of UBT Knowledge Center. For more information, please contact knowledge.center@ubt-uni.net. 


\title{
PROCESS OF STATE-BUILDING IN KOSOVO
}

\author{
Ngadhnjim Brovina, Adlum Ramadani \\ ILIRIA College, Republic of Kosovo \\ \{ngadhnjim.brovina, adlum.ramadani\}@uiliria.org
}

\begin{abstract}
The topic of state-building is a subject that has been continuously studied. To be fully understood, a case study should be included. Therefore, we have selected the case of Kosovo and the challenges of the process of state-building that Kosovo has had in the past. The purpose of this paper is to highlight the challenges that Kosovo's policy-making has faced along the road to statebuilding. The materials included in this scientific paper are from official documents from local and international institutions, as well as international and local authors from the field of state-building. The methodology used in this paper includes the descriptive method of events, analyzing them step by step to the stage of state-building, a process that continues to this day. The expected results from this paper are intended to reveal the challenging points that Kosovo politics has had how it has faced them and how it has overcome these challenges. The role of the international factor in the process of state-building is also to be shown. In the case of Kosovo, we had big challenges both abroad and internally. Internally, the unification of Kosovo policy and harmonization with the international factor are included. Internationally, it was the achievement of internationalization of Kosovo's case and achievement of recognition as a state.
\end{abstract}

Keywords:Kosovo, state-building, challenges, internal factor, international factor

\section{State building in Kosovo}

Peace building is a concept that fits in with state-building ideas. Regarding peace-building, there is a narrow and broad definition. As a narrow definition of peace building is the prohibition of violence and the achievement of the ceasefire, and as a broad definition is the achievement of a lasting peace, state building and the development of democracy. 145

The link between state-building and peace-building is very important: state-building primarily aim is transforming the state, giving a feeling of accountability while peace building aim is transforming social relations. Both have the common goal of strengthening state-society relations.146

${ }^{145}$ Santander, L. F. Monroy: Kosovo's peace-building: the effects of liberal state-building on ethnic reconciliation:, 2012, University of Birmingham, pg. 11, Accessed in (20.08.2017), Taken from: https:/www.academia.edu/7899724/KOSOVOS PEACE-BUILDING THE EFFECTS OF LIBERAL STATE BUILDING_ON_ETHNIC_RECONCILIATION

${ }^{146}$ Santander, L. F. Monroy: Kosovo's peace-building: the effects of liberal state-building on ethnic reconciliation:, 2012, University of Birmingham, pg. 11, Accessed in (20.08.2017), Taken from: https://www.academia.edu/7899724/KOSOVOS_PEACE-BUILDING_THE_EFFECTS_OF_LIBERAL_STATE BUILDING_ON_ETHNIC_RECONCILIATIONN 
The transformation of the state of Kosovo from a province, which de jure was considered a constituent part of Serbia in an independent and sovereign state, was not only the goal of the international factor, which through such division of territory would affect the future of the Balkans, given that Belgrade had already openly launched the new project of the Federal Republic of Yugoslavia, following the passing of UNSC Resolution 777147, where this resolution ended the existence of Yugoslavia, but also of the Kosovo's people themselves, who continued to be persecuted by Serbian forces under the orders of then-Serbian President Slobodan Milosevic, in particular after the 1995 Dayton Peace Agreement, where there were direct negotiations between American diplomat Richard Holbrooke and then President Milosevic, for removing Kosovo from the Belgrade agenda.148 US persistent attempts to remove people of Kosovo from this Serbian agenda resulted in military intervention of Serbian paramilitary forces in Kosovo's territory, which started the first Serbian offensive against the Kosovo's people and lasted until the adoption of UN Security Council resolution 1244 by the United Nations Security Council on June 10th 1999, when the Euro-Atlantic Alliance took a series of air strikes to make Serbian troops leave from Kosovo territory, from which the first phase of establishing the foundation of peace-building and statebuilding of Kosovo began.149

With the withdrawal of Serbian military forces, Kosovo was taken under the international protectorate, respectively under the UNIMIK administration whose mandate was determined based on the decision taken at the Security Council and after taking Kosovo under administration, UNMIK together with KFOR reached an agreement with Kosovo Liberation Army (KLA) to become a Kosovo Protection Corps supervised by the UNMIK mission in Kosovo to maintain the country's peace and stability, which greatly influenced the peace-building process in Kosovo, where later this element would be a component of the Kosovo state building formula.150 With the intervention of the international community in Kosovo, the process of establishing the foundation of the state of Kosovo begun with the direct investments of the European Union and the Council of Europe, who immediately after the stabilization of the situation, started building institutional facilities and opening a new chapter for the Kosovo's people. OSCE, another international factor, gave an even stronger push to the state-building process right after the war by organizing free and democratic elections at the municipal and central level.

It was UNMIK that also supervised the election affairs, which through the 'Constitutional Framework for Provisional Self-Government' opened Kosovo's door to the possibility of having its own provisional institutions (Assembly, President, Government and Court), to which it would gradually bear responsibility from the international factor.151 The process of democratization of Kosovo's state institutions started in November 2004 through central elections, where Kosovo already had created its political subjects, which were continuously supported and trained by international troops in Kosovo.152 This year, which was defining a fruitful future for Kosovo's future, was also going to be a risky task for the country's security institutions because in March

${ }^{147}$ Clarification of the resolution

148 Silander, D. \& Janzekovitz, J.: State-building and democracy:prosperity, representation and security in Kosovo:, Interdisciplinary Political and Cultural Journal, Vol. 14, NO. 1/2012, pg. 4142 .

${ }^{149}$ Lemay-Hébert, N.:State-Building from the Outside-In: UNMIK and Its Paradox:,pg. 67.

${ }^{150}$ Greiçevci, L.: The Case of Kosovo: From "International Statebuilding" to an "Internationally Supervised and Independent Country:, L'Europe en Formation 2008/3, pg.196.

${ }^{151}$ Constitutional Framework for the Provisional Self Government in Kosovo 2001

152 Greiçevci, L.: The Case of Kosovo: From "International Statebuilding" to an "Internationally Supervised and Independent Country:, L'Europe en Formation 2008/3, pg.198. 
2004 the first post-war riots occurred, which directly jeopardized the stability and the democratic spirit that had just begun to give light.153 In March, occurred the first attacks on the Serb community and their cultural objects, which sparked conflict between international defense troops and Serbian community and as a consequence of these riots, UNIMIK started to lose the successful performance which during the period September-October 2002 reached around $63.8 \%$ satisfaction evaluation, which later went to $20.7 \%$ as a consequence of not managing properly the situation between the Kosovo's people and the Serb community.154

Figure 1. Level of satisfacion with the work of main institutions in Kosovo ${ }^{155}$

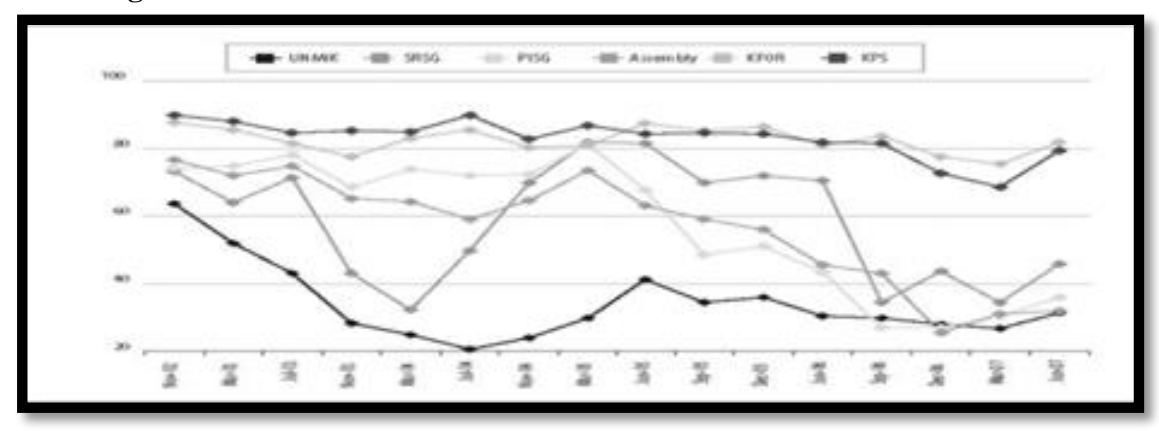

According to the chart above, we can see that the UNIMIK performance level fell to the worst in the riots of March 2004 while KFOR continued to stay above 80\%, making it the most trusted institution in the country. Despite the poor management of UNMIK, Kosovo politics continued to pursue progress towards achieving the ultimate goal of declaring Kosovo an independent and sovereign state. Initially, the path of establishing the foundations of the provisional government institutions was followed, then the process of institutionalization through the democratization of institutions, moving further with the decentralization and privatization of enterprises to enable free trade and at the same time the transfer monetary currency from Dinar to Mark and later to Euro.

All these steps were followed by the fact that the interim government and the Kosovo's people sought to define status by declaring independence, which was categorically opposed by Belgrade. Given Pristina's demand and Serbia's objections to status determination, the United Nations agreed to start negotiations between parties to find solutions, which would be acceptable on both sides and that it would not pose a risk for potential riots. Negotiations lasted for over 15 months, moderated by former Finnish President Martti Ahtisaari, who after all the attempts came out with a statement that the parties could not reach such a joint agreement and that given the current situation he recommends the international factor that Kosovo should gain the status of independence but to be supervised by internationals, who would make sure that the minority rights will be respected.

On February 17, 2008, with the agreement of the international factor, Kosovo was proclaimed an independent state, having its own flag and the identification hymn of the newest state in the world. With the declaration of independence, the influence of UNMIK and KFOR in Kosovo fades away,

${ }^{153}$ Greiçevci, L.: The Case of Kosovo: From "International Statebuilding" to an "Internationally Supervised and Independent Country:, L'Europe en Formation 2008/3, pg.198.

${ }^{154}$ Lemay-Hébert, N.:State-Building from the Outside-In: UNMIK and Its Paradox:,pg. 68.

${ }^{155}$ Lemay-Hébert, N.:State-Building from the Outside-In: UNMIK and Its Paradox:,pg. 68. 
as state institutions began to take their shape. But this did not mean full independence from the international community, as the state of Kosovo still had no stable institutions to face situations that could easily go out of control. Thus, a new international mission of the European Union was set up in Kosovo, which would have the duty to assist and oversee Kosovo's work in the area of justice, customs and politics. ${ }^{156}$ Based on researches conducted by international organizations, it was clear that with the creation of provisional governing institutions, Kosovo had taken over political responsibility in terms of building institutional capacities to ensure stability in the country

Figure 2. Table reflecting the indicators responsible for the political situation 2003-2009157 This UNDP report presents an overview of the indicators that according to Kosovo citizens were

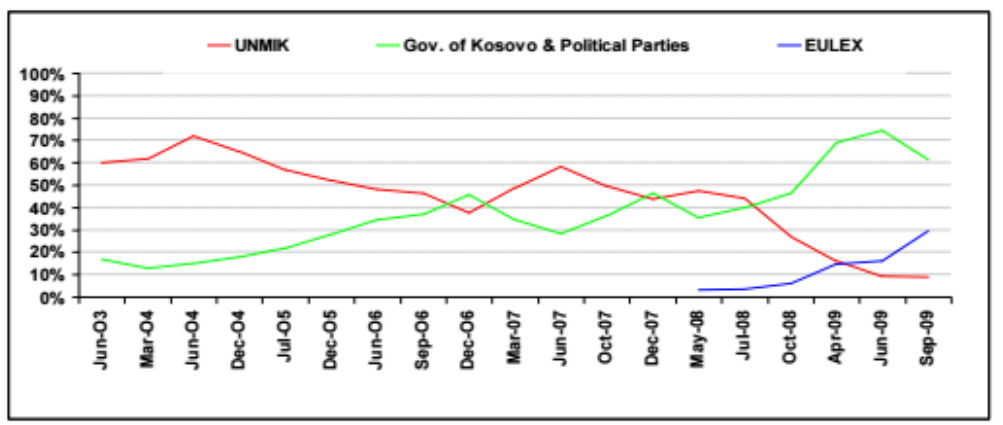

responsible for the political situation during the period 2003-2009, where UNMIK by June 2007 had a considerable responsibility for the political circumstances of that time while the Government of Kosovo and the Political Parties were the most responsible actors by going up to $75 \%$ after the declaration of independence.

The proclamation of the independence of the Kosovo state opened the door to take serious steps that would make the local institutions independent of international ones. This way, Kosovo started creating some very important institutions for the process that had started towards state-building, starting with Anti-Corruption Agency, which would serve as a mechanism for pursuing those who were responsible for post-war crimes, such institution was welcomed by the international factor. ${ }^{158}$ The arrival of EULEX, as an international mission to oversee Kosovo's work in the field of justice was a very positive initiative, which would certainly restore confidence of Kosovars in the improvement of the country's law system. Unfortunately, later it resulted to be a failed mission that could not manage the situation by exploding into scandals that would then endanger the credibility of the present international factor in Kosovo. This was because the mechanism that came to Kosovo to prevent the crime and corruption was becoming itself a part of it. ${ }^{159}$

${ }^{156}$ EULEX, Kosovo, European Union Rule of Law Mission in Kosovo, EU, http://www.eulexkosovo.eu/, April 2017

${ }^{157}$ Kosovo: The Building of a European State or Just Another State in Europe?, Faton Tony Bislimi, Dalhousie University, pg. 50, September 2010

${ }^{158}$ Kosovo: The Building of a European State or Just Another State in Europe?, Faton Tony Bislimi, Dalhousie University, pg. 52, September 2010

159 EU accused over its Kosovo mission: 'Corruption has grown exponentially', The Guardian, Accessed in April, 2017,https://www.theguardian.com/world/2014/nov/06/eu-accused-over-kosovo$\underline{\text { mission-failings }}$ 
Now that Kosovo declared independence, the next step after political stability and the establishment of sustainable institutions would be international co-operation to ensure economic stability, which would determine the fate of the newest state in the world. Based on a report issued by the Central Bank of Kosovo and the Kosovo Agency of Statistics in 2003, there was a clear picture of the main indicators of the economy after the declaration of independence.

Figure 3. Table reflecting main indicators of Kosovo's economy after the declaration of independence during the period 2009-2013 $3^{160}$

\begin{tabular}{|c|c|c|c|c|c|}
\hline Selected indicators & $\mathbf{2 0 0 9}$ & $\mathbf{2 0 1 0}$ & $\mathbf{2 0 1 1}$ & $\mathbf{2 0 1 2}$ & $\mathbf{2 0 1 3}$ \\
\hline Real growth of GDP (\%) & 3.5 & 3.2 & 4.4 & 2.5 & 3.1 \\
\hline GDP (million €) & 4007.8 & 4291.1 & 4769.8 & 4916.4 & - \\
\hline Inflation (annual average) & -2.4 & 3.5 & 7.3 & 2.5 & 1.8 \\
\hline Credits (million €) & 1289 & 1458.7 & 1698.1 & 1763.4 & 1805.8 \\
\hline Deposits (million €) & 1744.8 & 1936.9 & 2104 & 2279 & 2449.0 \\
\hline Exports (million €) & 165.3 & 295.9 & 319.2 & 276.1 & 293.9 \\
\hline Imports (million €) & 1935.5 & 2157.7 & 2492.3 & 2507.6 & 2450.4 \\
\hline
\end{tabular}

Meanwhile, if we take into consideration the report of the International Monetary Fund for Kosovo of July 2013, we see that the local economy was foreseen to have increased investments but decreased exports.

Figure 4. Real growth of Kosovo's economy for the period 2014-2018

\begin{tabular}{|c|c|c|c|c|c|c|}
\hline \multirow{2}{*}{} & $\mathbf{2 0 1 4}$ & $\mathbf{2 0 1 5}$ & $\mathbf{2 0 1 6}$ & $\mathbf{2 0 1 7}$ & $\mathbf{2 0 1 8}$ \\
\cline { 2 - 6 } & \multicolumn{4}{|c|}{ Projections based on Kosovo authorities and IMF staff (Real growth, percent) } \\
\hline Consumtion & 3.0 & 3.3 & 3.3 & 2.9 & 3.1 \\
\hline Invesment & 3.4 & 5.2 & 7.9 & 7.5 & 6.4 \\
\hline Exports & 12.1 & 11.8 & 11.7 & 9.7 & 9.2 \\
\hline Imports & 4.4 & 5.5 & 6.3 & 5.7 & 5.2 \\
\hline GDP & 4.2 & 4.5 & 5.0 & 4.5 & 4.5 \\
\hline $\begin{array}{c}\text { Memorandum item } \\
\text { (GDP millions of } € \text { ) }\end{array}$ & 5588 & 5959 & 6383 & 6806 & 7251 \\
\hline
\end{tabular}

Due to the low economic level and the lack of perspective, the Kosovo population decided to take the road to the West by the end of 2014 to continue until March 2015, hoping to get asylum in European countries. As a result of this flow of asylum seekers more than 5,200 students dropped out of schools to walk the streets of Belgrade to European Union countries, while according to figures it turns out that over 50,000 citizens abandoned the country. ${ }^{162}$

The Stabilization and Association Agreement was another element that influenced Kosovo's statemaking policy process which was signed on October $22^{\text {nd }} 2015$, between the EU and Kosovo and

${ }^{160}$ Central Bank of Kosovo and the Kosovo Agency of Statistics, 2003.

${ }^{161}$ Central Bank of Kosovo and the Kosovo Agency of Statistics, 2003.

${ }^{162}$ Exodus from Kosovo: Why thousands have left the Balkans, The Telegraf, Accesed in April 2017, http://www.telegraph.co.uk/news/worldnews/europe/kosovo/11426805/Exodus-fromKosovo-Why-thousands-have-left-the-Balkans.html 
entered into force on $1^{\text {st }}$ of April 2016. ${ }^{163}$ The agreement determined the establishment of new relations between them and that it would help Kosovo in creating reforms and opportunities for trade and investments. The agreement would also open Kosovo's door to membership in European family, which had already allocated a budget of 645.5 million Euros for Kosovo for the period 2014-2020, in order to create favorable conditions for necessary pre-accession reforms. ${ }^{164}$

The normalization of relations with Serbia, as part of the European Union agenda, was facing crisis regarding the implementation of agreements reached in Brussels by the parties, in particular during the period 2015-2016, when elections were held in Serbia, and after August 2016 they reached the initial stage of implementation after the Iber bridge in the northern part of Kosovo was opened. ${ }^{165}$

\section{Conclusion}

In this paper which aim was to elaborate a topic related to state-building with a case study of Kosovo, we tried to describe some of the most challenging elements of Kosovo policy making process over the years.

Since the end of the war in Kosovo in 1999, the process towards peace-building, transition of peace-building stages and the difficult journey towards state-building is divided in two phase. The first phase includes the peace-building from 1999-2008 and the state-building phase from 2008 when we proclaim independence continues to this day. Challenges have been specific at each stage. The peace-building phase involved the building of institutions in Kosovo, the return of refugees, free elections and infrastructure reconstruction. This was done in cooperation with the international factor and the UNMIK mission. The state-building phase has included certain negotiation periods up to the proposal or what we know as the Ahtisaari Package, whereby the declaration of independence in 2008 is achieved.

Thereafter we have the establishment of state institutions including the Constitution, Kosovo Security Forces, Intelligence Agency, etc and this phase has passed in cooperation with the international factor and the EULEX mission. After that, we have the challenges we are facing today, such as economic development, recognition of independence, membership in regional and international organizations.

If we look at it in general, Kosovo is seen as a success story by the international factor.

\footnotetext{
${ }^{163}$ Stabilisation and Association Agreement (SAA) between the European Union and Kosovo signed, European Council, Council of the European Union, Accesed in April 2017, http://www.consilium.europa.eu/en/press/press-releases/2015/10/27-kosovo-eu-stabilisationassociation-agreement/

${ }^{164}$ European Commission - Press release,Stabilisation and Association Agreement (SAA) between the European Union and Kosovo enters into force, http://europa.eu/rapid/press-release_IP-161184 en.htm

${ }^{165}$ Commission staff working document Kosovo* 2016 Report, Europian Commission, Brussels, 9 November 2016, pg.4
} 


\section{References}

15. Constitutional Framework for the Provisional Self Government in Kosovo 2001.

16. Commission staff working document Kosovo* 2016 Report, Europian Commission, Brussels, 9 November 2016.

17. Central Bank of Kosovo and the Kosovo Agency of Statistics, 2003.

18. EULEX, Kosovo, European Union Rule of Law Mission in Kosovo, EU, http://www.eulexkosovo.eu/, April 2017

19. EU accused over its Kosovo mission: "Corruption has grown exponentially", The Guardian, Accessed in (23.07.2017), Takem from: https://www.theguardian.com/world/2014/nov/06/euaccused-over-kosovo-mission-failings

20. European Commission - Press release, Stabilisation and Association Agreement (SAA) between the European Union and Kosovo enters into force, Accessed in (02.08.2017), Takem from: http://europa.eu/rapid/press-release_IP-16-1184_en.htm

21. Exodus from Kosovo: Why thousands have left the Balkans, The Telegraf, Accessed in (12.07.2017), Takem from:

http://www.telegraph.co.uk/news/worldnews/europe/kosovo/11426805/Exodus-from-KosovoWhy-thousands-have-left-the-Balkans.html

22. Greiçevci, L.: The Case of Kosovo: From "International Statebuilding" to an "Internationally Supervised and Independent Country:, L'Europe en Formation 2008/3.

23. Kosovo: The Building of a European State or Just Another State in Europe?, Faton Tony Bislimi, Dalhousie University, September 2010

24. Lemay-Hébert, N. :State-Building from the Outside-In: UNMIK and Its Paradox:.

25. Silander, D. \& Janzekovitz, J.: State-building and democracy:prosperity, representation and security in Kosovo:, Interdisciplinary Political and Cultural Journal, Vol. 14, NO. 1/2012.

26. Santander, L. F. Monroy: Kosovo's peace-building: the effects of liberal state-building on ethnic reconciliation:, 2012, University of Birmingham, Accessed in (20.08.2017), Taken from:

27. https://www.academia.edu/7899724/KOSOVOS_PEACEBUILDING_THE_EFFECTS_OF_LIBERAL_STATE BUILDING_ON_ETHNIC_RECONCILIATION

28. Stabilisation and Association Agreement (SAA) between the European Union and Kosovo signed, European Council, Council of the European Union, Accessed in (02.09.2017), Takem from: http://www.consilium.europa.eu/en/press/press-releases/2015/10/27-kosovo-eustabilisation-association-agreement/ 